\title{
Growth of Young Short-Necked Clam in the Artificial Tidal Flat Created by Using Solidification/Stabilization Techniques with Paper Sludge Ash-based Coagulants
}

\author{
Daizo Imai $^{* 1}$, Satoshi Kaneco, Kiyoyuki Egusa, Hideyuki Katsumata and Kiyohisa Ohta \\ Department of Chemistry for Materials, Graduate School of Engineering, Mie University*2 \\ Tohru Suzuki \\ Environmental Preservation Center, Mie University \\ Ahmed H. A. Dabwan \\ Faculty of Chemical Engineering Technology, Tati University College
}

\begin{abstract}
Paper sludge (PS), which is mainly made from paper factories waste can be utilized for useful applications. We have developed an in situ solidification system for treatment of sea bottom sediments, the "Hi-Biah-System (HBS) ", by using incinerated PS coagulant. The solidified material produced by HBS was applied for restoration of the marine environment ecosystem (i. e. Tidal flat, Seaweed and Seagrass bed, etc.). The number of benthos individuals in the constructed artificial tidal flat has shown similarity to those observed in the natural tidal flat. In this report, we showed the monitoring data of the growth of young short-necked clams (Ruditapes philippinarum) in the artificial tidal flat. The remarkably large growth was observed in the artificial tidal flat rather than natural tidal flat. We believe that these solidified materials were useful for restoring marine ecosystem.
\end{abstract}

Keywords : artificial tidal flats, paper sludge, dreaded sediments, little short-necked clam, Ago Bay

\section{Introduction}

Paper sludge (PS) exhausted from Paper pulp industries were reached magnitude amount of several million tons per year in the whole areas, and also paper sludge ash (PS ash) which were incinerated for reduction reached several hundred thousand tons. Because the PS ash is composed of minute fiber, kaolin, and talc whose raw material is the paper manufacture lees, etc., it has been researched that the solidification function and the cohesion function like cement are provided ${ }^{1)}$. Authors developed the cohesion solidification agent that had solidification action and cohesion action by keeping a function of ettringite after the hydration in PS $\mathrm{ash}^{2}$. PS ash coagulant made possible to separate water and solid from muddy dredged sediment in lower pressure than conventional dehydration method ${ }^{3)}$.

Dredging the organically rich sediments is one of the important ways to help ecosystem to achieve its prosperity. By the past dredging business, the dredged sediment was

${ }^{* 1} 1577$ Kurimamachiya-cho, Tsu-shi, Mie 514-8507, Japan

${ }^{* 2} \mathrm{E}-$ mail : daizo@ice.email.ne.jp dewatered to the fourth grade of construction soil by using flocculant PAC and large-sized dehydration machine, then disposed to the land. But there is no reclamation disposal ground, we are annoyed by high construction cost and vast processing area. Moreover, effective use for the dredged sediment contain a lot of abundant organic content is preferable for beneficial resources. It was not necessary to dehydrate to hardness like the past when the dredged spoil was used for the tidal flat creation and eelgrass place creation, and it reached the conclusion a simpler device is the best.

In Mie pref., dredging construction has been conducted for environmental restoration every year. In order to reduce the water content from watery mud sediments $\mathrm{Hi}$ Biah System (HBS) was developed ${ }^{2)}$. The water content of the dredged sediments was reduced from $90-\mathrm{wt} \%$ before treatment to $60-\mathrm{wt} \%$ after treatment. The solidified material produced by HBS has applied for restoration of the marine environment ecosystem (i.e. Tidal flat, Seaweed and seagrass bed ${ }^{2)}$, Marine block ${ }^{4)}$, etc.).

It is well known that tidal flats are important areas that perform many environmental functions such as serving as 
a habitat for benthic organisms, recreational activities as well as playing a role in water purification and biological productivity. However, in recent years, many tidal flats have been lost as a result of industrial and urban development of coastal areas. According to the Ministry of the Environment, Japan, the total area of natural tidal flats was about $826 \mathrm{~km}^{2}$ in the $1940 \mathrm{~s}$; however, by the $1980 \mathrm{~s}$, approximately $40 \%$ of these natural flats had been $\operatorname{lost}^{5)}$. Especially in Ago Bay, Japan, to date, about $70 \%$ of the natural tidal flats have been lost.

We have been conducted the investigation for the restoration of benthic ecosystems in the constructed artificial tidal flat over 2 years ${ }^{6}$. In the artificial tidal flat the number of benthos individuals has been shown to be similar to those observed in a natural tidal flat. In this report, in order to evaluate the re-productivity, we investigated the growth of young short-necked clams (Ruditapes philippinarum) in the artificial tidal flat.

\section{Experimental}

\subsection{Study area, solidification method and constructed tidal flats building}

The study site is located in Ise-Shima National Park, a semi-enclosed area around the Shima peninsula that is connected to the Pacific Ocean via a very narrow $(1.5 \mathrm{~km}$ width) and shallow (25 $\mathrm{m}$ water depth) entrance of the bay (Fig. 1 \& Photo.1). The interior part of the bay is complexly divided into many branch bays. The natural tidal flat analyzed in our study lies in the inner part of a branch bay in the Tategami area in Ago bay. The amplitude of the flat varies from 0.5 to $3.0 \mathrm{~m}$ and its inclination is $1 / 10$. The constructed tidal flats were built in the same
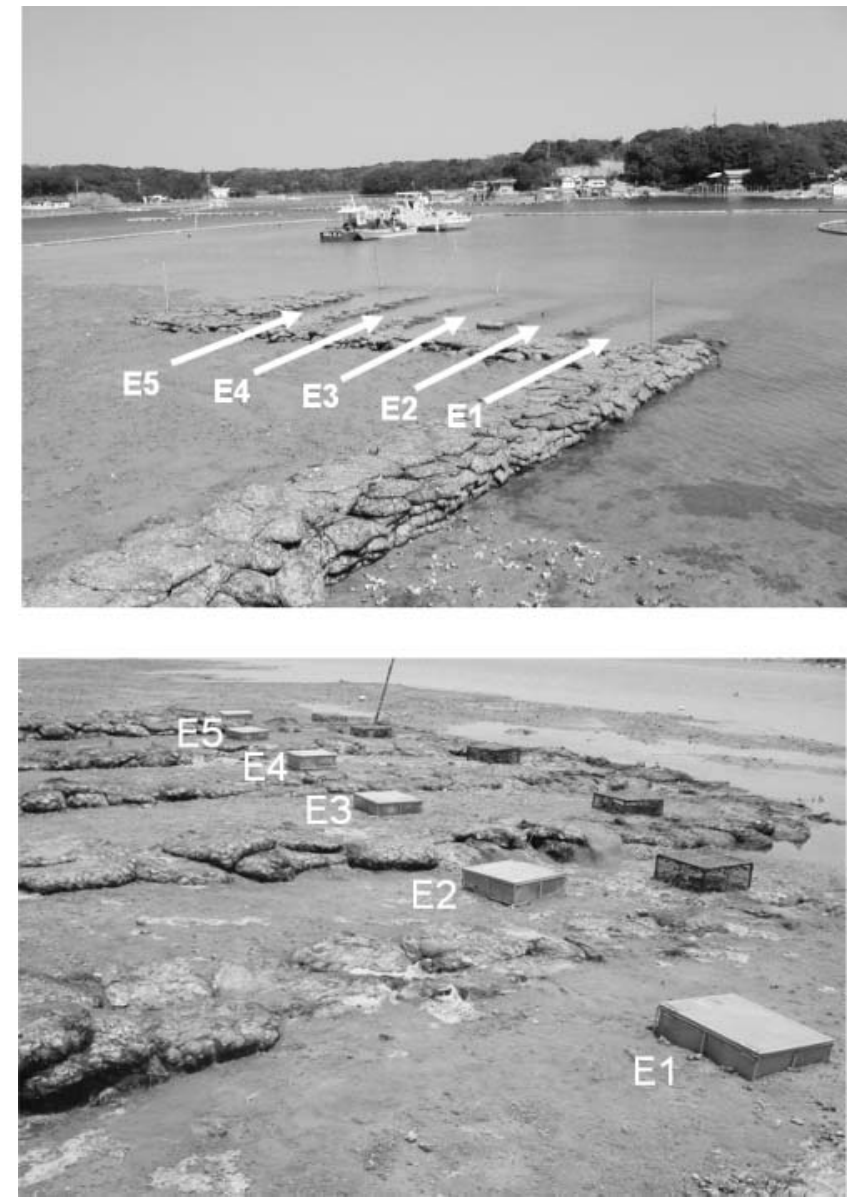

Photo. 1 Artificial tidal flat created in Tategami, Ago Bay (Cultivating cage of Little short-necked clam)

area (natural tidal flat, C 3 and S 3). The constructed tidal flat was built from March to April 2005 in Tategami, Ago

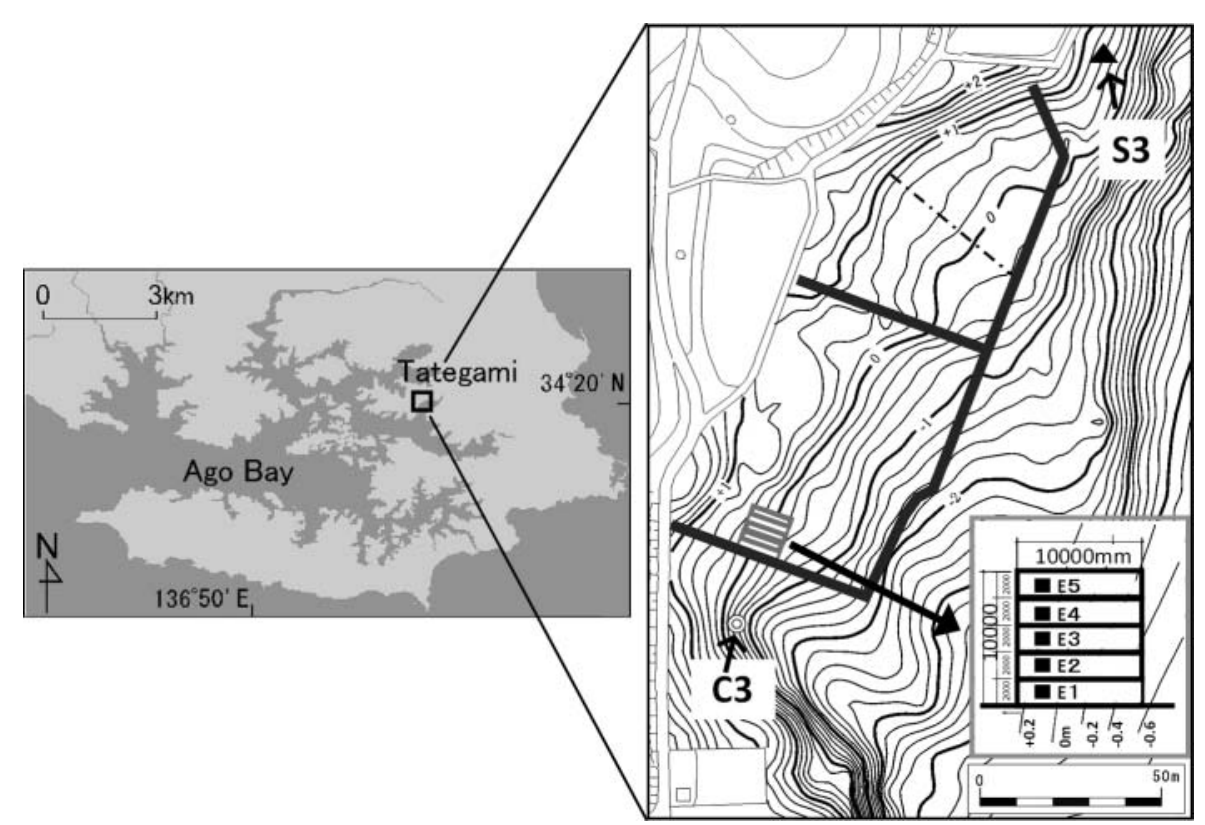

Fig. 1 Experimental location of Tategami, Ago Bay 
Bay as shown in Photo.2. It was then divided into 5 sections (E 1 to E 5), each with an area of $10 \mathrm{~m}$ length $\times 2 \mathrm{~m}$ width $\times 0.5 \mathrm{~m}$ depth. Five sections of the tidal flat were constructed by using different materials for exploring the

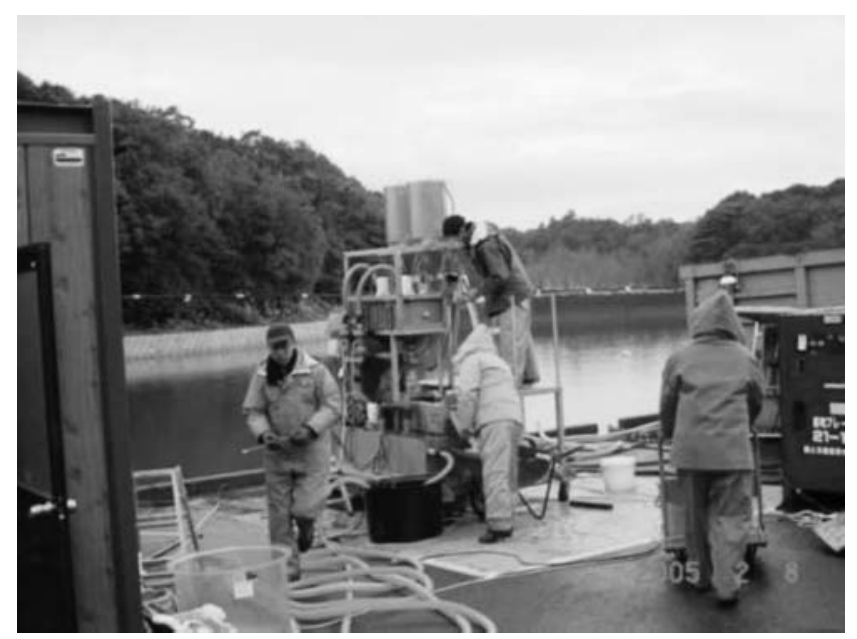

Photo. 2 The solidification method "HI-BIAH-SYSTEM" created for treatment of bottom sediment better conditions of artificial tidal flats. The procedures for constructing the artificial tidal flats are briefly summarized in Table 1.

We monitored the physico-chemical parameters and biological characteristics of the natural (C 3) and constructed tidal flats (E 1-E 5) every 3 months from construction. The parameters examined were water content (WC), loss on ignition (LOI), total organic carbon (TOC), chemical oxygen demand (COD), chlorophyll a, acid volatile sulphide (AVS), Oxidation-reduction potential (ORP) and $\mathrm{pH}$.

2.2 Monitoring of growth of the young short-necked clam

Stainless mesh (mesh size is $1 \mathrm{~mm}$ ) container $(600 \mathrm{~mm}$ $\times 500 \mathrm{~mm} \times 300 \mathrm{~mm}$ ) containing approximately 2000 young short-necked clams (Ruditapes philippinarum) were placed in all sections of the artificial tidal flat (E 1E 5) and natural tidal flat (C 3 and S 3). The clam size of the deployment started was about $2.5 \mathrm{~mm}$ length, which cultivated from larva in the Fishery Laboratory of Chiba Pref., then were transferred to the artificial tidal flat. The

Table 1 Brief summary of the procedures for constructing artificial tidal flats

\begin{tabular}{|c|c|c|}
\hline Section & E1 & E2 \\
\hline Procedure & $\begin{array}{l}\text { (1) Addition of } 1.5 w t \% \text { soil } \\
\text { conditioner. } \\
\text { (2) Dewatering to } 60 \% \text {. } \\
\text { (3) Mixing of muddy sediment of (2) } \\
\text { and sand with a ratio of } 3: 7 \text {. } \\
\text { (4) Construction of tidal flat with } \\
\text { the material of (3). }\end{array}$ & $\begin{array}{l}\text { (1) Addition of } 1.5 \mathrm{wt} \% \text { soil } \\
\text { conditioner. } \\
\text { (2) Dewatering to } 60 \mathrm{wt} \% \text {. } \\
\text { (3) Addition of } 20 \mathrm{wt} \% \text { soil } \\
\text { conditioner. } \\
\text { (4) Formation of pellet. } \\
\text { (5) Construction of tidal flat with } \\
\text { pellet of (4) and sand with a ratio of } \\
3: 7 \text {. }\end{array}$ \\
\hline Section & E3 & E4 \\
\hline Procedure & $\begin{array}{l}\text { (1) Construction of tidal flat with } \\
\text { sand. }\end{array}$ & $\begin{array}{l}\text { (1) Addition of } 5 w t \% \text { gypsum } \\
\text { coagulant. } \\
\text { (2) Dewatering to } 60 w t \% \text {. } \\
\text { (3) Mixing of muddy sediment of (2) } \\
\text { and sand with a ratio of } 3: 7 \text {. } \\
\text { (4) Construction of tidal flat with } \\
\text { the material of (3). }\end{array}$ \\
\hline Section & E5 & Natural tidal flat \\
\hline Procedure & $\begin{array}{l}\text { (1) Addition of } 2 w t \% \text { PAC. } \\
\text { (2) Dewatering to } 40 w t \% \text {. } \\
\text { (3) Addition of } 20 w t \% \text { solidification } \\
\text { agent (waste steel slag). } \\
\text { (4) Construction of tidal flat with } \\
\text { the material of (3) and sand with } \\
\text { weight ratio } 3: 7 .\end{array}$ & $\begin{array}{l}\text { C3;Muddy tidal flat } \\
\text { S3;Sandy tidal flat }\end{array}$ \\
\hline
\end{tabular}


container was covered with sediment in $15 \mathrm{~cm}$ and fixed on the tidal flat, then cleaned at every 2 weeks.

Growth of the short-necked clams (Survival rate, Length and Weight) was then monitored in May 2006 (1 month), Aug. (4 months), Nov. (7 months), April 2007 (12 months) and Jul. 2007 (15 months) after April 2006 deployment.

The condition factor (CF) of short-necked clams was measured by using equation (1) in Jul. 2007 (15 months) from 20 individuals.

$\mathrm{CF}(\%)=($ clam tissue dry weight/shell dry weight $) \times$ 100

\section{Results and discussion}

Firstly, in this study, it becomes clear that the rapid recovery of a creature is seen after construction and it is in the environmental condition that is equal to a natural tidal flat several months later as a result of continuation investigation for approximately two years about the physicochemical characteristics and recovery situation of macrobenthos in the constructed tidal flat and natural one ${ }^{6)}$. Fig. 2 depicts the population density (a), biomass (b) and species (c) of macrobenthos in the constructed tidal flats and natural tidal flats. On the constructed tidal flat, the population density and biomass were close to zero after 1 month, but after 3 months the population density increased relative to that observed in the natural tidal flat. After 2 years of monitoring, despite the temporal increase and decrease, the species of macrobenthos reached the maximum level after $3-6$ months of construction. It was suggested that a proper living density was maintained as a tidal flat ecosystem because the species of macrobenthos were constant afterwards, and it functioned as a steady tidal flat similar to a natural tidal one.
Next, the change variation of shell length in the young short-necked clams in artificial tidal flats (E 1-E 5) and natural tidal flats (C 3, S 3) were shown in Fig. 3. The change in the shell length in E 1 was $3.9 \pm 1.2 \mathrm{~mm}$ one month later, $8.0 \pm 2.2 \mathrm{~mm} 4$ months later, $17.3 \pm 2.9 \mathrm{~mm} 7$ months later, $20.1 \pm 3.2 \mathrm{~mm} 12$ months later and $23.6 \pm$ $2.8 \mathrm{~mm} 15$ months later after the initial shell length of 2.5 $\pm 0.9 \mathrm{~mm}$. This growth rate corresponds to about $17 \mathrm{~mm}$ a year (about $1.4 \mathrm{~mm}$ a month). These values indicated a similar in E 2, E 4, E 5 and $\mathrm{C} 3$. On the other hand, in E 3 and $\mathrm{S} 3$, the shell length after 15 months was $17.1 \pm 3.1$ $\mathrm{mm}, 15.4 \pm 3.0 \mathrm{~mm}$ respectively, and this growth levels were lower than other examined districts.

The final shell length and the condition factor of the short-necked clam, and the physico-chemical parameters in clam cultivating ground were shown in Table 2. In E 3 and S 3 sandy fraction was dominant regarding as less than $20 \%$ mud, on the other hand, in other experiment district a lot of mud was dominant, these results support that a proper organic content in the mud fraction contribute the growth of the young short-necked clam. However, when E 4 and E 5 were compared for E 1 and E 2, survival rate indicated the value that about $30-60$ percent is low in E 4 and E 5 regardless of a similar growth level (shell length and wet weight). In E 4 and $\mathrm{E} 5$, the value of COD was low about 10-20 percent though the mud fraction was equal to E 1 and E 2. It was suggested that the organic matter in E 1 section was useful to the short-necked clam growth than other section, because the COD value generally indicated the organism resolved easily from the TOC value. In addition, the remaining of the short-necked clams with large shell length was confirmed in E 1 compared with other section (Fig.4). The shell length in E 3 and S 3, sandy tidal flats, was smaller than E 1 though

Table 2 Particle fractions and Little short-necked clam parameters (Final)

\begin{tabular}{|c|c|c|c|c|c|c|c|}
\hline \multirow{2}{*}{ St. } & \multicolumn{2}{|c|}{ Little short-necked clam parameters ${ }^{\mathrm{a}}$} & \multicolumn{3}{|c|}{ Particle fractions of sediment ${ }^{\mathrm{b}}$} \\
\cline { 2 - 8 } & $\begin{array}{c}\text { Shell } \\
\text { length } \\
(\mathrm{mm})\end{array}$ & $\begin{array}{c}\text { Wet } \\
\text { weight } \\
(\mathrm{g})\end{array}$ & $\begin{array}{c}\text { Condition } \\
\text { factor }) \\
(\%)\end{array}$ & $\begin{array}{c}\text { Survival } \\
\text { rate } \\
(\%)\end{array}$ & $\begin{array}{c}\text { TOC } \\
(\mathrm{mg} / \mathrm{g})\end{array}$ & $\begin{array}{c}\text { COD } \\
(\mathrm{mg} / \mathrm{g})\end{array}$ & $\begin{array}{c}\text { Mud } \\
\text { fraction } \\
(\%)\end{array}$ \\
\hline E1 & $23.6 \pm 2.8$ & $2.6 \pm 1.0$ & $9.1 \pm 1.0$ & 10.2 & 5.9 & 9.3 & 30.1 \\
\hline E2 & $21.1 \pm 2.9$ & $1.8 \pm 0.8$ & $9.1 \pm 2.1$ & 10.8 & 4.4 & 6.0 & 28.7 \\
\hline E3 & $17.1 \pm 3.1$ & $1.0 \pm 0.5$ & $8.3 \pm 1.5$ & 16.3 & 2.1 & 1.7 & 19.0 \\
\hline E4 & $24.8 \pm 2.8$ & $3.4 \pm 1.2$ & $9.0 \pm 1.3$ & 4.6 & 4.6 & 5.9 & 31.1 \\
\hline E5 & $22.1 \pm 2.7$ & $2.1 \pm 0.8$ & ND & 7.8 & 4.7 & 4.6 & 26.7 \\
\hline C3 & $23.1 \pm 3.3$ & $2.5 \pm 1.1$ & $9.0 \pm 0.9$ & 2.7 & 12 & 23 & 74.3 \\
\hline S3 & $15.4 \pm 3.0$ & $0.7 \pm 0.5$ & $7.0 \pm 2.0$ & 32.6 & 2.8 & 2.0 & 20.1 \\
\hline
\end{tabular}

a) Monitoring was performed at $15^{\text {th }}$ July 2007 ( 15 months).

b) Particle fractions were measured at $22^{\text {nd }} \mathrm{Aug}$. 2007. The value of section S3 was measured at the same time of a).

c) Condition factor $(\%)=($ clam tissue dry weight/shell dry weight) $x 100 .(\mathrm{ND}$; not measured $)$ 

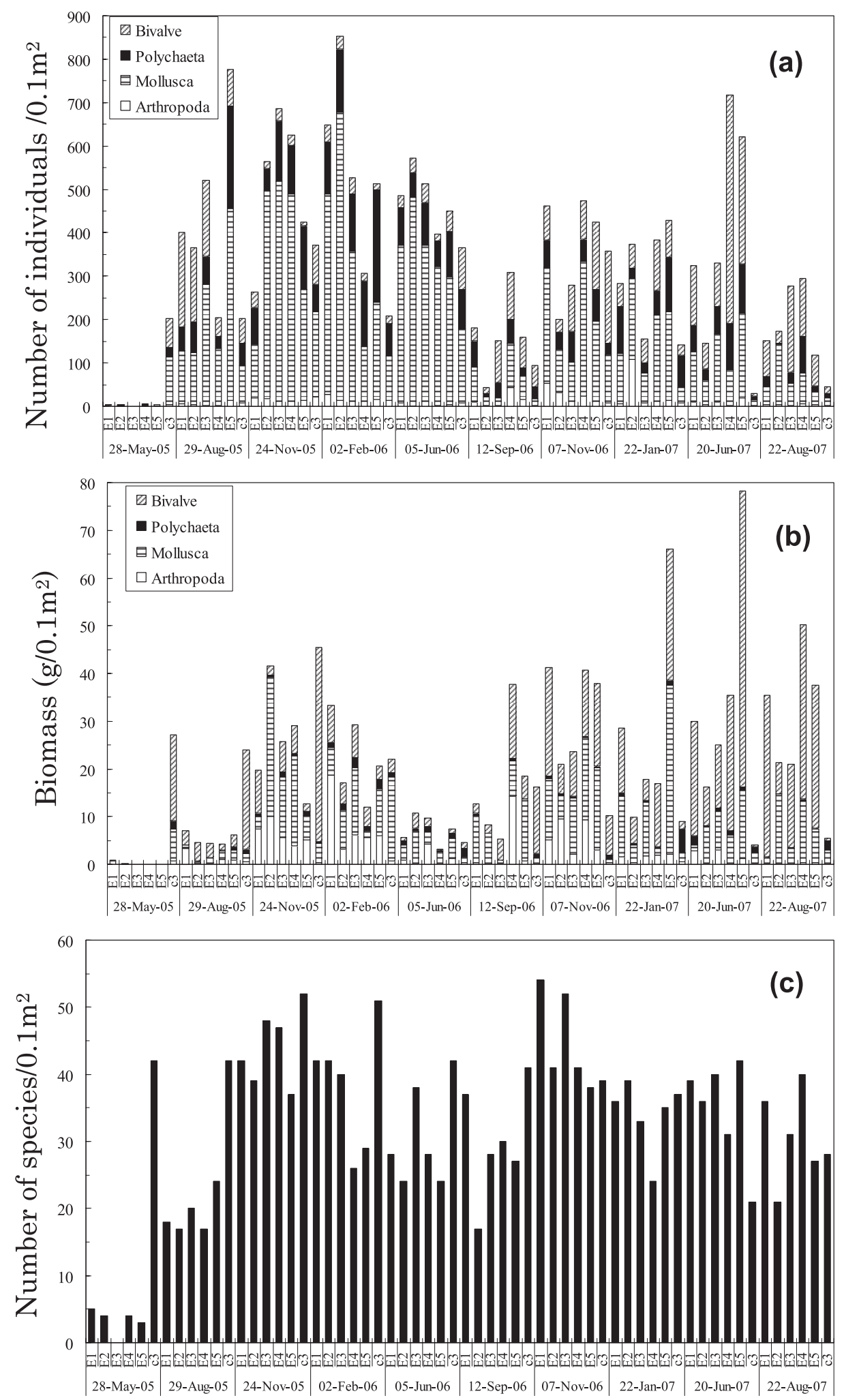

Fig. 2 Time course variation of Benthos on the Artificial and Natural tidal flat (a ; Individual, b ; Wet weight, c ; Species)

there were a lot of numbers of individuals in the basket. Photo. 3 was shown the before and after experiment of short-necked clam.

Kokubu et al. reported that an optimum COD value for macrobenthos in the artificial tidal flat was about $10 \mathrm{mg} / \mathrm{g}$ from the benthic characteristic research ${ }^{7}$. In the present study, the value of COD in E 1 (PS ash) shows $10 \mathrm{mg} / \mathrm{g}$ continuously, it suggests it is suitable as biotope of the benthos. In addition, the COD value was continued constantly. In other words, these results suggested that the PS solidifi- 


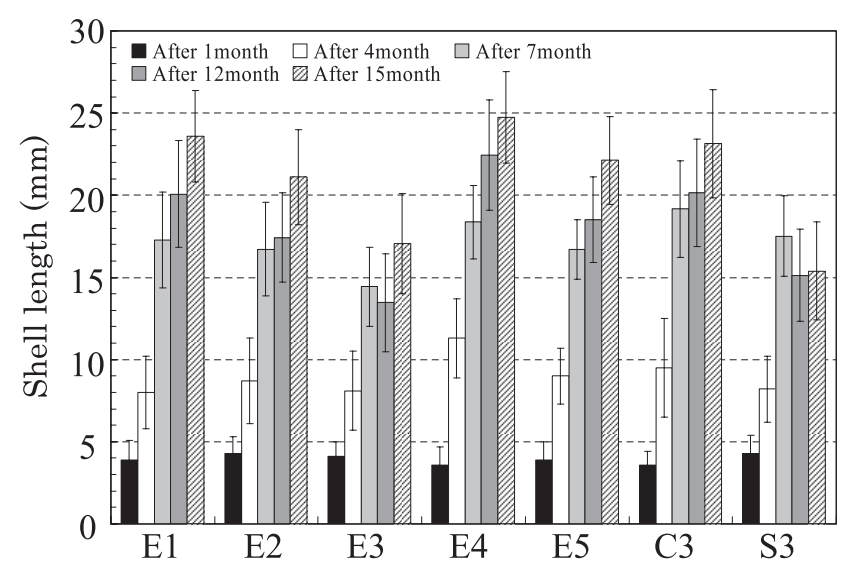

Fig. 3 Measurement of Shell length of the Young shortnecked clam

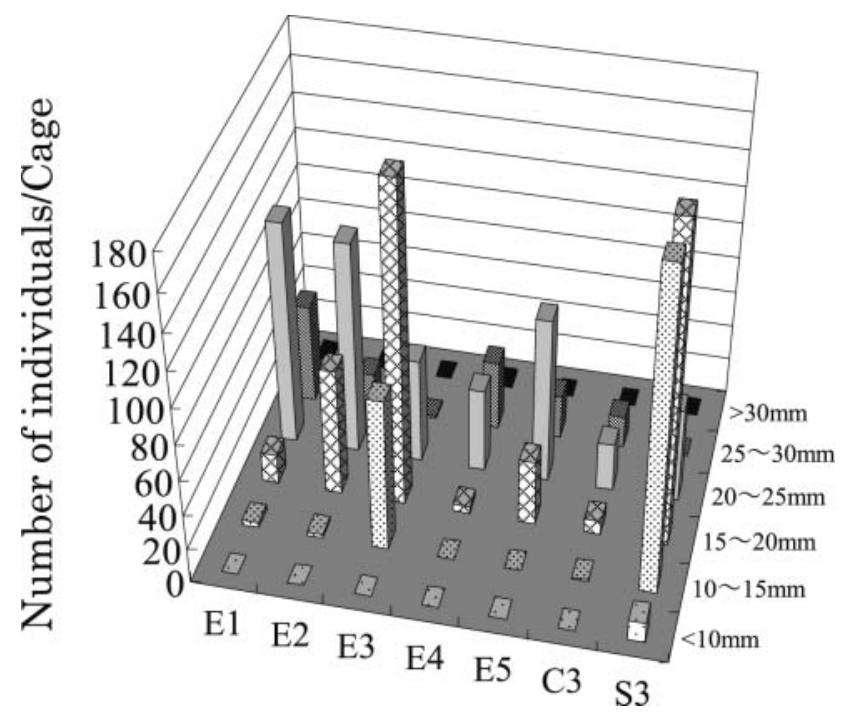

Fig. 4 Alive individuals to Shell length of Little shortnecked clam at final monitoring

cation materials has prevention function of the shape collapse of the soil particle and the organic material's outflow was prevented from physical environment factor (water flow etc.,) in the tidal area, because of its solidification function and re-mud prevention function in the water. On the other hand, it had been reported to increase the ratio of the PS ash for the dredging sludge that elution $\mathrm{pH}$ tended to increase, but the change from $\mathrm{pH} 8$ in deployment to $\mathrm{pH}$ 7.5 similar to the natural tidal flat was seen in $\mathrm{E} 1$ section (PS ash). In E 5 using slag solidification materials the value of $\mathrm{pH}$ showed 9.5 , but changed to $\mathrm{pH} 8$ afterwards. We performed making artificial tidal flat by adjusting the ratio of the dredging sludge to regulate the organic amount for the purpose of improving the biological diversity. It will be necessary to examine the quality of bottom environment such as $\mathrm{pH}$ levels when changed the ratio of improved materials and influence on biological diversity in
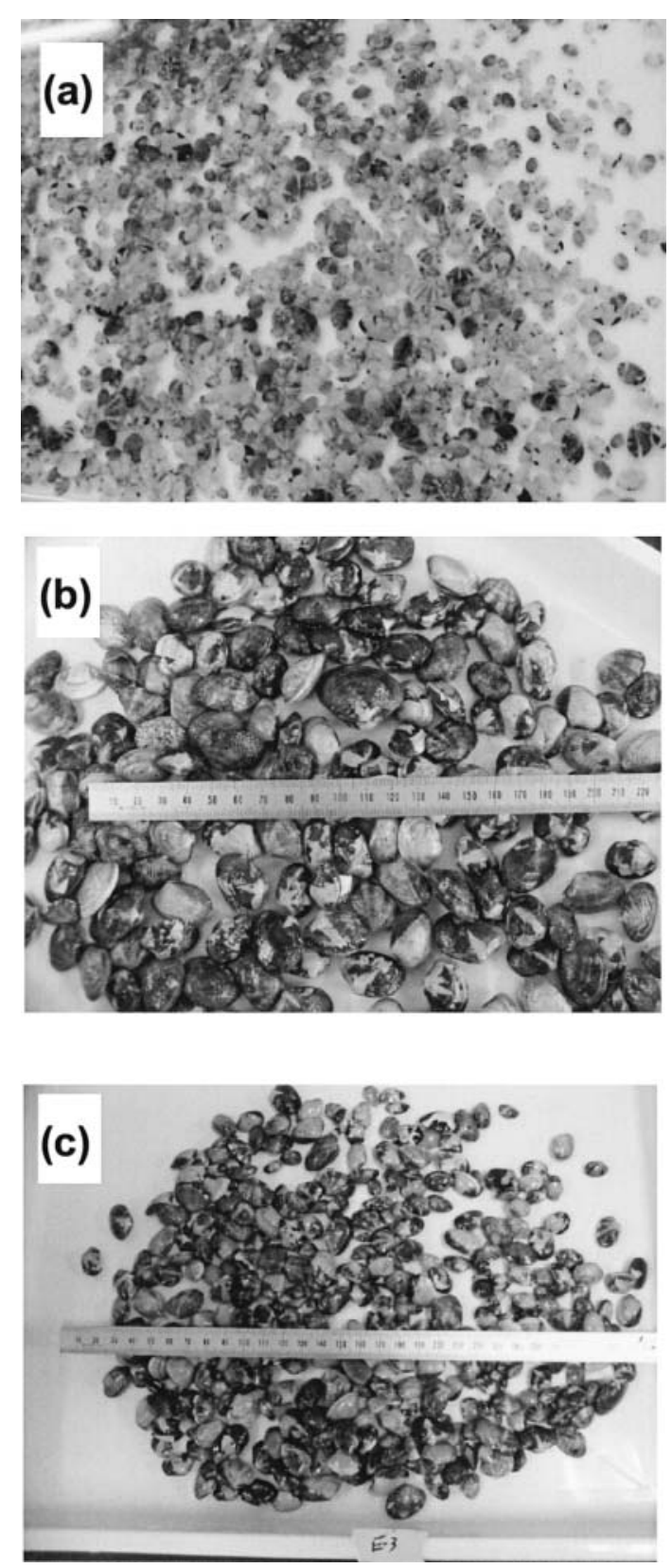

Photo. 3 Little short-necked clam (Ruditapes philippinarum) in the cultivating cage (a ; Start, b ; Section E 1, c ; Section E 3)

future.

In the previous study, authors observed the growth and survival rate of adult short-necked clam (25 mm shell length) prior to the experiment of this young short-necked clam, and reported that the growth of adult indicates approximately 1.5 times a year ${ }^{8}$. This result was similar to a breeding result in Tokyo Bay. There are many studies by the basket examination as the study for production of short-necked clams improvement, self-support in the natural tidal flat ${ }^{9), 10,11)}$ and reported the growth of shell length $9 \mathrm{~mm} / 10$ months (initial $20 \mathrm{~mm}$ ), $10 \mathrm{~mm} / 9$ months (initial $18 \mathrm{~mm}$ ) in the adult clam, $20 \mathrm{~mm} / 9$ months (initial 

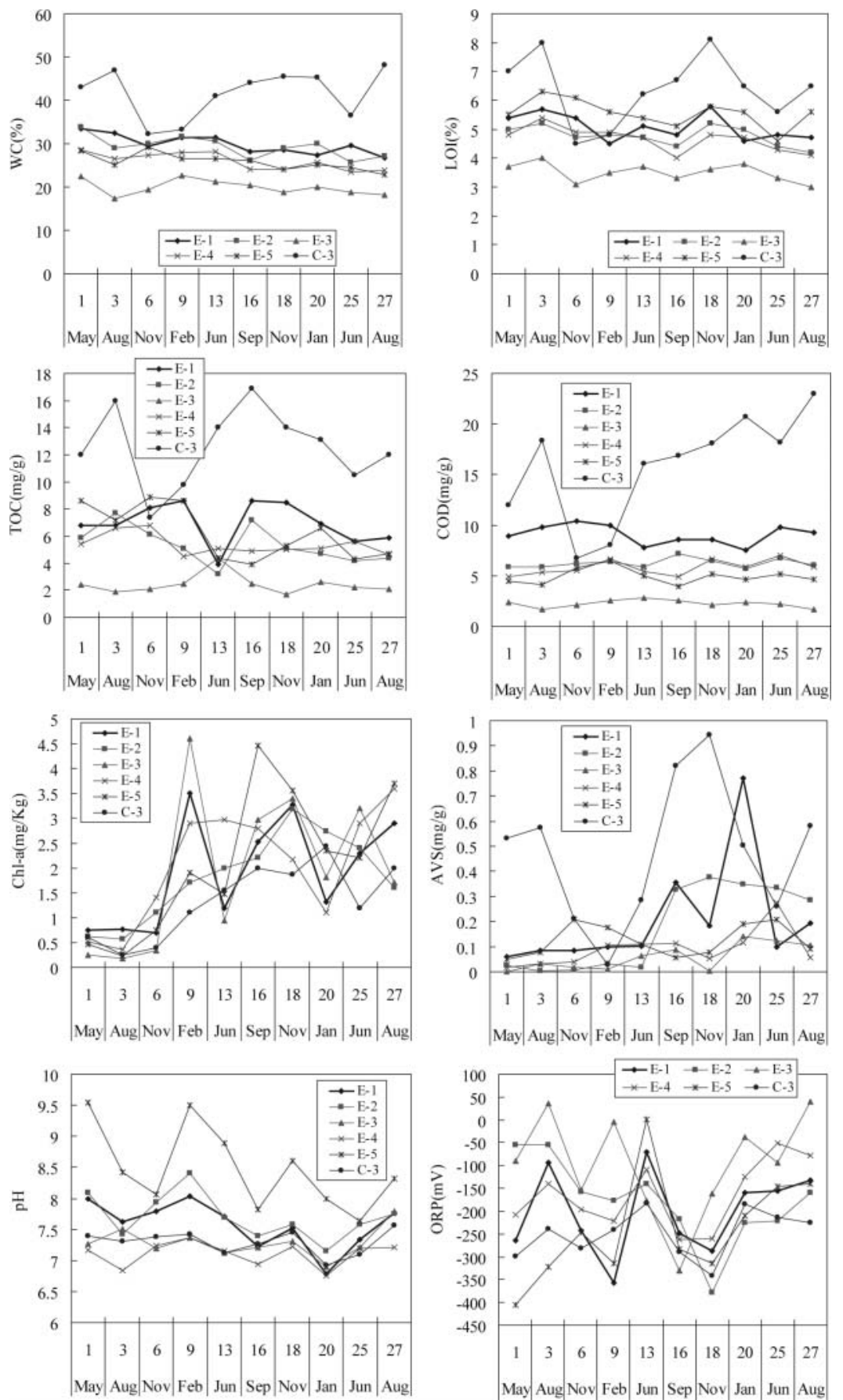

Fig. 5 Time course variation of physico-chemical parameters on the Artificial and Natural tidal flat

$8 \mathrm{~mm}$ ) in the young clam. On the other hand, there are few study regarding as the cultivating examination of the short-necked clam in the artificial tidal flat, and reported that is not good a survival rate by oxygen deficient water in the summer ${ }^{12)}$. In addition, there are a lot of creation examples using sandy materials, but there are few creation examples of the artificial tidal flat using dredged sludge and there are few example of the short-necked clam growth examination in such a sandy tidal flat ${ }^{13), 14)}$.

When the short-necked clam hatches from an egg, metamorphose through (a floating larva) for the plankton period of approximately 2-3 weeks, and it is to a very small shellfish of approximately $0.3 \mathrm{~mm}$, and grow up afterwards, and it is well known to become $1 \mathrm{~mm}$ of shell length after approximately $2-3$ months. Because the observation is very difficult as for the study about the floating period equal to the initial life cycle of the short-necked clam, there are few examples, and it is estimated the laying eggs occur twice a year in spring and fall, in the middle of June from the end of May, the end of October from the end of September in the golden period, in Ise Bay ${ }^{15)}$. In recent years, the development of the identification method of 
the short-necked clam floating period by the monoclonal fluorescent antibody method（a Patent No. 29130265） has advanced, and it is reported for larva that the bottom environment after the arrival influences the next group structure in the tidal flat, west coast, Ise $\mathrm{Bay}^{16), 17)}$. If the population of short-necked clam on the tidal flat is maintained by the introduction of the artificial tidal flat, it will be lead to the reproduction in the bay, and can expect future resources recovery in future.

\section{Conclusion}

We developed an in situ solidification system for treatment of sea bottom sediments and created the artificial tidal flat, then observed the growth of young short-necked clam in the tidal flat for useful marine resources. Particularly, the growth that was higher than others was confirmed in the experiment ward using the PS ash material. The reason is not clear in detail, but it is thought that a particle size and the organic matter content of the treated dredged sediment by using PS ash were most suitable. We have demonstrated that the environmental restoration project in Ago Bay is expected to be a natural model case in term of reconstruction/reinforcement for the revival of short-necked clam revived. Furthermore, by the creation of tidal flat in future, we can expect that the recovery of the marine resources and the additional value of recreation progress.

\section{References}

1) Yoshino, H., Mochizuki, Y., Tanaka, T., Tyazono, Y., Proceedings of the Japan National Conference on Geotechnical Engineering 38 ${ }^{\text {th }}$, (2003).

2) Imai, D., Kato, T., Dabwan, A., Harada, I., JAPAN TAPPI JOURNAL, 60, 9, 80-88 (2006).

3) Katakura, N., Ueno, S., Kobayashi, M., Imai, D., Dabwan, A., Maekawa, K., Proceedings of the Japan Conference on Japan Society of Civil Engineering $60^{\text {th }}$, (2005).
4) Imai, D., Dabwan, A., Kaneco, S., Katsumata, H., Suzuki, T., Hossain, M. Z., Nakashima, K., Kato, T., Ohta. K., The CIGR Ejournal, vol. X. (June), Manuscript BC 08003 (2008).

5) Ministry of the Environment, Annual Report on the Environment (White Paper), (2004).

6) Imai, D., Kaneco, S., Dabwan, A., Katsumata, H., Suzuki, T., Kato, T., Ohta, K., International Journal of Soil, Sediment and Water, vol 1, no 2., Article 5 (2008).

7) Kokubu, H., Okumura, M., Ueno, S., Takayama, Y., Yuasa, S., Journal of Coastal Engineering, 52, 11961200 (2005).

8) Imai, D., Dabwan, A. H. A., Kato, T., Kaneco, S., Katsumata, H., Suzuki, T., Ohta, K., Océanis, 34, 201-213 (2008).

9) Yamaguchi, K., Uchida, A., Journal of Fisheries Engineering, 42 (1), 39-48 (2005).

10) Kakino, J., The Japanese Society of Fisheries Science, 62(3), 376-383 (1996).

11) Kiyabu, Y., Kurokawa, A., Annual Report on the Oita Institute of Marine and Fisheries Science, 29-41 (1999).

12) Miyazaki, H., Yamazaki, T., Tanimoto, T., Kohata, K., Hiwatari, T., Journal of Water and Waste, 47(2), 142149 (2005).

13) Iwamoto, Y., Okamura, T., HEDORO, 91, 28-34 (2004).

14) Yamochi, S., Hirai, K., Fujiwara, S., Journal of Coastal Engineering, 50, 1246-1250 (2003).

15) Hagita, K., Ishikawa, T., Aquaculture Science, 32 (4), 213-215 (1985).

16) Miyawaki, D., Sekiguchi, H., Fisheries Science, 65, 817829 (1999).

17) Nanbu, R., Mizuno, T., Kawakami, T., Kubota, K., Sekiguchi, H., The Japanese Society of Fisheries Science, 72(4), 681-694 (2006).

(Manuscript accepted 30 August, 2011) 